\title{
The Effect of Financial Slack, Institutional Ownership, Media Exposure on Carbon Emission Disclosure with Solvability Ratio as a Moderating Variable
}

\author{
Kuatina Nur Aini ${ }^{1}$, Rima Murtiningsih ${ }^{1 *}$, Niswah Baroroh ${ }^{1}$, Kuat Waluyo Jati ${ }^{1}$ \\ ${ }^{1}$ Department of Accounting, Faculty of Economics, Universitas Negeri Semarang \\ "Corresponding author.Email: rimamurtiningsih05@gmail.com
}

\begin{abstract}
This research aims to analyse the effect of financial slack, institutional ownership, media exposure on carbon emission disclosure with solvability ratio as a moderating variable. In addition, the population of this study is 109 manufacturing companies basic \& chemical sector and plantation companies listed in the Indonesia stock exchange in the period 2017-2019. The sample was selected using the purposive sampling technique so that it produced 59 samples with 177 units of analysis. This research uses absolute difference analysis. The result shows that financial slack and media exposure have a significant and positive effect on carbon emission disclosure and institutional ownership has no significant effect on carbon emission disclosure. Then the solvability ratio succeeded in moderating the effect of financial slack and media exposure on carbon emission disclosure. The solvability ratio is not able to moderate institutional ownership on carbon emission disclosure. Therefore, it can be concluded that carbon emission disclosures are increasing when companies have financial and media advantages that focus on implementing the company's carbon emissions disclosures. If the company has a high solvability ratio will make the company more careful about carbon emission disclosure decisions.
\end{abstract}

Keywords: Carbon Emission Disclosure, Financial Slack, Institutional Ownership, Media Exposure, Solvability Ratio

\section{INTRODUCTION}

The advancement of industrial activities has an impact on a country's economic growth, but there will be environmental problems to follow. Global warming is one of the environmental problem plantations are one of the sources of man-made emissions, that arise due to industrial activities that produce greenhouse gases [1]. Based on IPCC (Intergovernmental Panel on Climate Change) since pre-industrial, the surface air temperature has increased by $1.53^{\circ}$ the collapse of the aluminium factory in Jakarta in 2019 due to the production process's smoke has exceeded predetermined limits based on the Decree of the Governor of DKI Jakarta No. 670 off 2000, the effect of industrial activities that causes pollution [2], [3].
Based on the pages of National Geographic [4], the peat forest can absorb $\mathrm{CO}_{2}$ from the atmosphere which is then stored in the soil that would reduce the effects of greenhouse gases. However, in Indonesia and Malaysia peat forests have been converted to oil palm plantations, which produce $16.6 \%$ and $27.9 \%$ of carbon emissions, respectively. especially $\mathrm{CO}_{2}$, methane, and nitrogen dioxide.

According to WRI (World Resources Institute)[5], Indonesia is one of the largest contributors to greenhouse gas emissions and the largest contributor to forest-based emissions in the world rank 6th. Indonesia in 2015 joined the UNFCCC and became acquainted with the Kyoto Protocol, an entity operating in the industrial sector with more attention to the environment [6]. The Government of Indonesia 
has also ratified through Law No. 17 of 2004[7] and Presidential Regulation No. 61 of 2011 on the National Action Plan for Reducing Greenhouse Gas Emissions[8].

The existence of an entity affects its surrounding environment. Companies require activities in harmony with the values and norms of the neighborhood. The company needs to produce a carbon emission disclosure to obtain legitimacy from the stakeholder. The report is used to inform the public that companies can avoid the effects of greenhouse gases from operational activities[9]. The participation of the company can be seen from annual reports and sustainability reports that provide information on the carbon emission disclosure. however, the carbon emission disclosure in Indonesia remains a voluntary disclosure [10].

Research on carbon emission disclosure still finds inconsistent results. The previous research have found that the effect of financial slack on carbon emission disclosure produces inconsistent results research by [11][12][13][14]. The previous research have found that the effect of institutional ownership on carbon emission disclosure produces inconsistent results research by [15][16][17][10]. Meanwhile, research the previous research, have found that the effect of media exposure on carbon emission disclosure produces inconsistent results [18][15][19][20].

Based on previous research that showed inconsistent results, the researchers want to reexamine the factors that could affect carbon emission disclosure. This research aims to analyze the effect of financial slack, institutional ownership, media exposure on carbon emission disclosure with solvability ratio as a moderating variable. The originality of this research lies in the addition of the solvability ratio as a moderating variable. The solvability ratio owned by the company plays a role in the company's ability to pay its obligations. So when the company has financial slack, institutional ownership, media exposure, the solvability ratio can influence the company's decision when determining the carbon emission disclosure.

There are three theories that support this research. The first, theory of legitimacy. Legitimacy theory as an organization that strives to create harmony between social values and acceptable behavioral norms in the larger social system of which they are a part [21]. The company will try to implement carbon emission disclosures in the annual report and sustainability report to meet the needs of public information that the company's operational activities are following the values of the community. The company doing a carbon emission disclosure to keep it gained legitimacy.
The second theory that supports the voluntary implementation of carbon emission disclosures can be explained through agency theory[6]. Agency theory defines as the relationship between the agent and the principal, the agent as the manager be elected by the principal to manage resources effectively, efficiently, and in decision making [22]. The agent has a strong reason not to always act in the interests of the principal, this causes information asymmetry. Therefore, companies are expected to disclose their social and environmental responsibility reports, one of which is carbon emission disclosure. A carbon emission disclosure is expected to minimize the occurrence of information asymmetry[10].

The last of the theory is a signaling theory, said that was developed to find out that information related to the company's state in the future is known to the management of the company more than the stakeholders[23]. The signaling theory suggests that a well-quality company will give a signal the market is expected to differentiate good companies. The implementation of carbon emission disclosure is expected to proved information to interested parties[24].

Financial slack is a company's financial availability that exceeds the necessary needs and can be used to finance other activities[25]. Financial slack describes the companies having more financial resources[26]. According to agency theory, the existence of differences in the interests of the principal assumes that managers have more information will result in information asymmetry. The manager can overcome that problem by presenting a broader amount of information, one of which is a carbon emission disclosure. This is to show that the manager is still acting following the wishes of the principal. Companies with good finances can carry out carbon emission disclosures, especially companies that have financial slack. Several researchers found that financial slack had a positive effect on carbon emission disclosures[11][12].

\section{$\mathrm{H}_{1}$ : Financial slack has a significant positive} effect on carbon emission disclosure

Institutional ownership is share ownership that can be owned by an institution and corporate institutions such as insurance, banks, and other institutional ownership. Based on agency theory, it states that there are differences in interests between the agent and the principal, causing information asymmetry. So that there is no difference in the information by managers and stakeholders, it would require a broader amount of information including a carbon emission disclosure. The companies can exist in the present run when considering the profits, people, planets; And innovations care about the management of companies in this regard. So that management will be monitored 
and encouraged to implement carbon emission disclosures by institutional ownership. Several researchers found that institutional ownership has a positive effect on carbon emission disclosures [16][17].

\section{H$_{2}$ : Institutional ownership has a significant positive effect on carbon emission disclosure}

Media exposure is one of the mechanisms for public supervision through the information presented in the media. Based on the legitimacy theory which states that the role of environmental responsibility disclosure is carried out by companies to try the legitimacy of their companies. The role of the media can encourage companies to publish environmental activities and carbon emission disclosures. This is to show the public that the company's activities are following the values and norms around the community. Some researchers also found financial slack on carbon emission disclosures [18][15].

$\mathrm{H}_{3}$ : Media exposure has a significant positive effect on carbon emission disclosure

Companies with the good financial condition are able to expand the information disclosed, including carbon emission disclosures. The solvability ratio is the ratio used to measure the company's assets financed using debt[27]. According to the legitimacy theory, the solvability ratio can influence decisions regarding the policy for implementing carbon emission disclosures. At a time when a company has a solvability, it would affect the company's policy of the carbon emission disclosure. Because the company has debt obligations that must be paid, to provide information that the company is still able to survive and pay its obligations. So that when the company has financial slack but there is solvability, the company will reconsider its policy and possibly cancel the implementation of carbon emission disclosures.

\section{H4: Solvability ratio significantly moderates the effect of financial slack on carbon emission disclosure}

The companies that have institutional ownership can supervise the management of information regarding the future that corporate capabilities that would play a role in climate change, the information that would be needed is a carbon emission disclosure. Solvability ratio is the ratio used to measure operating assets financed by debt[27]. The theory of legitimacy at the level of solvability could influence the decision regarding the implementation of the policy of the carbon emission disclosure. So it can influence the legitimacy of the corporations. When according to the signal theory a good company will give a signal to the market so that it is expected to be able to distinguish good and bad companies. So it requires more extensive information. The existence of solvability will make the institutional ownership encourage management to bring about the carbon emission disclosures to give a signal to stakeholders that the company's condition is doing well and can survive even though the company has debt.

\section{H5: Solvability ratio significantly moderates the effect of institutional ownership on carbon emission disclosure}

Carbon emission disclosures need to be reported through the media to inform the public that the company has carried out environmental activities to participate in climate change. The solvability ratio is the ratio used to measure the company's assets financed using debt[27]. According to the legitimacy theory, the solvability ratio can influence decisions regarding the policy for implementing the carbon emission disclosures. So that it can affect the legitimacy of the company. Then according to the signal theory, there is a difference in information between management and stakeholders and results in information asymmetry. Therefore, carbon emission disclosures need to be reported through the company's website to inform the public that the company can finance its debts and can carry out environmental activities to participate in climate change

$H_{6}$ : Solvability ratio significantly moderates the effect of media exposure on carbon emission disclosure

\section{RESEARCH METHOD}

This is a quantitative study with the object of research from a manufacturer of materials \& chemicals companies and plantation companies listed in the Indonesian Stock Exchange. The population in this research is 109 companies and used the purposive sampling technique. The remaining 59 companies with 4 years observation period (2017-2019), thus there is 177 unit analysis. Data is collected using documentation techniques from annual reports and sustainability reports from www.idx.co.id and the company's website. Data analysis methods used is descriptive analysis and inferential statistics that include classical assumption test, absolute difference test, and hypothesis test, with score $\alpha=0.05$. This research model used the moderated regression analysis, which can be seen in the following equations 1:

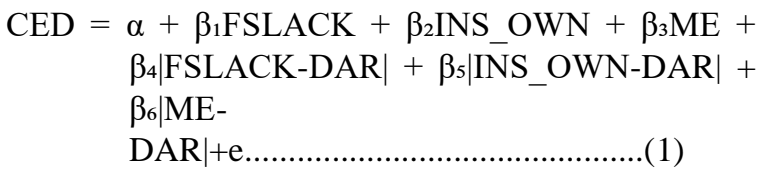

description:

CED $=$ Carbon Emission Disclosure 


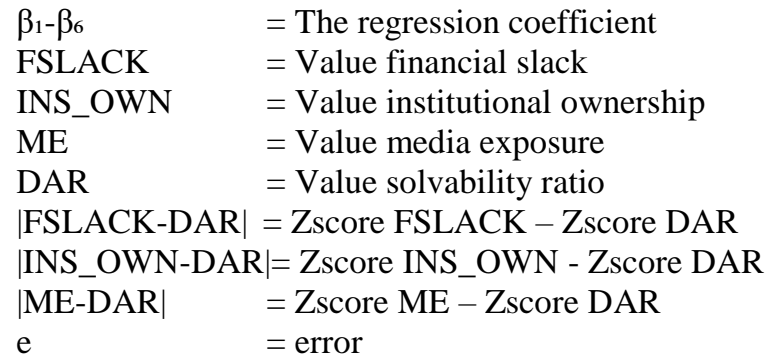

\section{Carbon Emission Disclosure}

The dependent variable used in this study is carbon emission disclosure. The extent of the carbon emission disclosure can be determined by the carbon disclosure project (CDP). Carbon emission disclosure is measured through a checklist index which is divided into five categories, namely environmental change, greenhouse gas emissions, energy consumption, greenhouse gas reduction, and carbon emission costs and accountability. Under these five categories will be divided into 18 items. The maximum score that can be achieved by a company is 18 by giving a score of 1 if the company implements one of these items. Then to determine the size of carbon emissions can be calculated using the following formula which refers to research[20]:

$$
C E D=\frac{\text { Total item disclosed }}{\text { total item index checklist }} \times 100 \%
$$

\section{Financial Slack}

The first independent variable used is financial slack, which can be measured by the following formula which refers to research[11]:

FSLACK $=\frac{\text { Cash and Cash Equivalens }}{\text { Total sales }}$

\section{Institutional Ownership}

The second independent variable used is institutional ownership, it can be measured by the following formula which refers to research[15]:

$$
\text { INSOWN }=\frac{\text { Stock Owned by Institution }}{\text { Outstanding Stock }} \times 100 \%
$$

\section{Media Exposure}

The third independent variable used was media exposure, which could be measured whit dummy variables. Which would score 1 for the change that gives a description of a carbon emission disclosure over a company's website and score 0 for a company that does not provide information about carbon emission disclosure over a company's website[1].

\section{Solvability Ratio}

The moderating variable used in this study is the solvability ratio using the debt to asset ratio (DAR) proxy and can be calculated using the formula referring to research[10].

$D A R=\frac{\text { Total Liability }}{\text { Total Asset }} \times 100 \%$

\section{RESULTS AND DISCUSSION}

Table 1 shows the results of descriptive statistics consisting of the minimum, maximum, mean, and standard deviation of the variables of carbon emission disclosure, financial slack, institutional ownership, solvability ratio. While the media exposure variable as measured by the dummy variable, resulting in the percentage of $58 \%$ of companies that were informed through the website and $42 \%$ of companies that did not

Table 1. Descriptive Statistics

\begin{tabular}{|l|c|c|c|c|c|}
\hline & $\mathbf{N}$ & Minimum & Maximum & Mean & $\begin{array}{c}\text { Std. } \\
\text { Deviation }\end{array}$ \\
\hline CED & 177 & .056 & .611 & .323 & .166 \\
\hline FSLACK & 177 & .003 & 1.365 & .173 & .239 \\
\hline INSOWN & 177 & .009 & .997 & .536 & .330 \\
\hline DAR & 177 & .063 & 1.107 & .504 & .229 \\
\hline
\end{tabular}

Table 2. Regression Test Results

\begin{tabular}{|l|c|c|c|}
\multicolumn{1}{c}{} & \multicolumn{1}{c}{$\begin{array}{c}\text { Beta } \\
\text { coefficient }\end{array}$} & \multicolumn{1}{c|}{ Sig } & Description \\
\hline FSLACK & 0.085 & 0.000 & Accepted \\
\hline INS_OWN & -0.006 & 0.668 & No Accepted \\
\hline ME & 0.061 & 0.000 & Accepted \\
\hline FSLACK_DAR & -0.100 & 0.349 & Accepted \\
\hline INSOWN_DAR & -0.031 & 0.250 & No Accepted \\
\hline ME_DAR & 0.082 & 0.020 & Accepted \\
\hline
\end{tabular}

inform through the media. The results of the classical assumption test in this study were good. Based on table 2 shows a summary of the results of hypothesis testing. The regression equation in this study is in equation 2 .

$$
\begin{aligned}
\mathrm{CED}= & 0.338+0.085 \text { FSLACK }-0.006 \text { INSOWN })+ \\
& 0.061 \mathrm{ME}-0.100 \mid \text { FSLACK-DAR } \mid-0.031 \\
& \mid \text { INSOWN-DAR }|+0.082| \mathrm{ME}- \\
& \text { DAR .........(2) }
\end{aligned}
$$

\section{The Effect of Financial Slack on Carbon Emission Disclosure}

Companies that have good finances especially those financial slack companies can carry out more environmental activities, to expand the carbon emission disclosure information to a greater extent and the information it contains can be qualified. So that the financial slack owned by the company can affect the implementation of carbon emission disclosure. This result is consistent with a researcher who says a high financial slack can affect the quality of carbon emission disclosure [11][12]. 


\section{The Effect of Institutional Ownership on Carbon Emission Disclosure}

Institutional ownership cannot influence the management decisions about the implementation of carbon emission disclosure. This can be seen based on table 1 of the results of descriptive statistical analysis which shows that the mean institutional ownership by de company's sample is moderate. The institutional ownership is not large in the sample of companies allows for a less strong for companies in this industry to make carbon emission disclosure. These results agree with researchers claim a high or low institutional ownership in the companies can not affect the extent of carbon emission disclosure [15][16].

\section{The Effect of Media Exposure on Carbon Emission Disclosure}

The role of the media can push companies to publish environmental activities and carbon emission disclosure. The environmental activities are published to inform the public that the company has made efforts to participate in climate change. It is also used to get legitimacy from the community, that companies have carried out activities according to the values and norms of the surrounding environment. The media exposure played a role to push a company to published the carbon emission disclosure to achieve its legitimacy, along with form researchers [18][15].

\section{The Effect of Financial Slack on Carbon Emission Disclosure with Solvability Ratio As A Moderator}

The solvability ratio has proved capable of weakening the financial slack impact on the carbon emission disclosure. The solvability ratio (DAR) will influence the manager's decision to use financial slack to meet his economic or corporate performance. The acquisition agreement would provide a loan payment in advance, and it would exclude the implementation of the environment and the carbon emission disclosure below.

\section{The Effect of Institutional Ownership on Carbon Emission Disclosure with Solvability Ratio as a Moderator}

The solvability ratio is not able to strengthen or weaken the implementation of carbon emission disclosures. This is because the average institutional ownership by the companies is moderate. Because of this, institutional owners do not encourage companies to carbon-emissions disclosure. The presence of debt in the company also does not affect institutional ownership because they may think that management has taken into account the debt so there is no need to take steps to bring the stakeholders that the company's condition is still fine. Based on the results of descriptive statistics, the average DAR is moderate. So that management has good managerial skills related to the settlement of obligations so that institutional ownership has good confidence in the company's debt management. So management has a good managerial ability associated with liability completion, then institutional ownership has good confidence in the management of corporate debt.

\section{The Effect of Media Exposure on Carbon Emission Disclosure with Solvability as a Moderator}

The solvability ratio can strengthen the effect of media exposure on carbon emission disclosure. the increase in the company's solvability will require a broader amount of information to coping asymmetric information between management and stakeholder. Then is a necessary carbon emission disclosure posted on a company's website tells the public that a company can pay for the debt and can do the environmental activities to participate in climate change. Published the information will show that the company has a chance to survive and going concerned.

\section{CONCLUSION}

The companies that have sufficient financial availability will prove that they are ready to implement carbon emission disclosure. Companies choose to disclose more information, such as carbon emission disclosures when there is more oversight from stakeholders through various existing media. When the company has debt, it will make the company's management consider policies that still make the company's good name look good in the eyes of stakeholders. Meanwhile, the existence of institutional ownership owned by the companies does not encourage companies to conduct carbon emission disclosures.

The researchers should examine the variable of the council's expertise in the board of climate change on the disclosure of carbon emissions. However, the information is not all were reported by the sample companies. Information can be obtained by contacting directly sample companies. So that researchers cannot examine the variables of expertise the board in climate change. It is suggested that future research should use the expertise variable on the board in climate change. Because expertise the board in climate change can encourage companies to carry out more extensive carbon emission disclosure. Corporate boards understand better how to tackle global warming and contribute to climate change.

\section{REFERENCES}

[1] R. Jannah and D. Muid, "Analisis Faktor-Faktor Yang Mempengaruhi Carbon Emission Disclosure Pada Perusahaan Di Indonesia," Diponegoro J. Account., vol. 3, no. 2, 2014, pp. 1000-1010. 
[2] IPCC, "Global Warming of 1.5 Derajat C," Intergovermental Panel on Climate Change, 2021. https://www.ipcc.ch/.

[3] "Keputusan Gubernur Prov DKI Jakarta No. 670 Tahun 2000 Tentang Penetapan Baku Mutu Emisi Sumber Tidak Bergerak Di Propinsi DKI Jakarta."

[4] “Climate Change," National Geoghrapic, 2021. https://www.nationalgeographic.com/.

[5] "Menilai Transparansi Target Emisi Gas Rumah Kaca Pasca-2020 dari 8 Negara Penyumbang Emisi Terbesar," World Resorces Institute, 2021. https://wri-indonesia.org/id/.

[6] M. Kılıç and C. Kuzey, "The Effect Of Corporate Governance On Carbon Emission Disclosures: Evidence From Turkey," Int. J. Clim. Chang. Strateg. Manag., vol. 11, no. 1, 2019, pp. 35-53, doi: 10.1108/IJCCSM-07-2017-0144.

[7] 'Undang-Undang RI Nomor 17 Tahun 2004 Tentang Protokol Kyoto atas Konvensi Kerangka Kerja Perserikatan Bangsa-Bangsa Tentang Perubahan Iklim.”

[8] "Peraturan Presiden No 61 Tahun 2011 Tentang Rencana Aksi Nasional Penurunan Emisi Gas Rumah Kaca."

[9] D. C. Probosari and W. Kawedar, "Analisis FaktorFaktor Yang Mempengaruhi Carbon Emission Disclosure Dan Reaksi Saham," Diponegoro J. Account., vol. 8, no. 3, 2019, pp. 1-16.

[10] N. P. Halimah and H. Yanto, "Determinant of Carbon Emission Disclosure at Mining Companies Listed in Indonesia Stock Exchange," Int. Conf. Econ. Bus. Econ. Educ., vol. 3, no. 10, 2018, pp. 127-141, doi: 10.18502/kss.v3i10.3124.

[11] L. Chithambo and V. Tauringana, "Company Specific Determinants Of Greenhouse Gases Disclosures," J. Appl. Account. Res., vol. 15, no. 3, 2014, pp. 323-338, doi: 10.1108/JAAR-11-20130087.

[12] G. A. Alfani and V. Diyanty, "Determinants of Carbon Emission Disclosure," J. Econ. Business, Account. Ventur., vol. 22, no. 3, 2020, pp. 333-346, doi: 10.14414/jebav.v22i3.1207.

[13] C. J. Kock, J. Santaló, and L. Diestre, "Corporate Governance and the Environment: What Type of Governance Creates Greener Companies?," J. Manag. Stud., vol. 49, no. 3, 2012, pp. 492-514, doi: 10.1111/j.1467-6486.2010.00993.x.

[14] D. Y. Anggraeni and C. D. Djakman, "Slack Resources , Feminisme Dewan, Dan Kualitas Pengungkapan Tanggung Jawab Sosial Perusahaan," J. Akunt. dan Keuang. Indones., vol. 14, no. 1, 2017, pp. 94-118.

[15] J. Wang, L. Song, and S. Yao, "The Determinants
Of Corporate Social Responsibility Disclosure: Evidence From China," J. Appl. Bus. Res., vol. 29, no. 6, 2013, pp. 1833-1847, doi: 10.19030/jabr.v29i6.8220.

[16] A. Alhazaimeh, R. Palaniappan, and M. Almsafir, "The Impact of Corporate Governance and Ownership Structure on Voluntary Disclosure in Annual Reports among Listed Jordanian Companies," Procedia - Soc. Behav. Sci., vol. 129, no. 1, 2014, pp. 341-348, doi: 10.1016/j.sbspro.2014.03.686.

[17] Z. Borghei-Ghomi and P. Leung, "An Empirical Analysis of the Determinants of Greenhouse Gas Voluntary Disclosure in Australia," Account. Financ. Res., vol. 2, no. 1, 2013, pp. 110-127, doi: 10.5430/afr.v2n1p110.

[18] C. Dawkins and J. W. Fraas, "Coming Clean: The Impact of Environmental Performance and Visibility on Corporate Climate Change Disclosure," J. Bus. Ethics, vol. 100, no. 2, 2011, pp. 303-322, doi: 10.1007/s10551-010-0681-0.

[19] R. A. Majid and I. Ghozali, “Analisis Faktor-Faktor Yang Mempengaruhi Pengungkapan Emisi Gas Rumah Kaca Pada Perusahaan Di Indonesia," Diponegoro J. Account., vol. 4, no. 4, 2015, pp. 111.

[20] B. B. Choi, D. Lee, and J. Psaros, “An Analysis Of Australian Company Carbon Emission Disclosures," Pacific Account. Rev., vol. 25, no. 1, 2013, pp. 58-79, doi: $10.1108 / 01140581311318968$.

[21] J. Dowling and J. Pfeffer, "Organizational Legitimacy: Social Values and Organizational Behavior Between The Organizations Seek To Establish Congruence," Univ. Calif. Press, vol. 18, no. 1,1975 , pp. 122-136.

[22] M. C. Jensen and W. H. Meckling, "Theory Of The Firm: Managerial Behavior, Agency Costs And Ownership Structure," J. financ. econ., vol. 3, no. 4, 1976, pp. 305-360.

[23] A. C. Utama and A. Muid, "Pengaruh Current Ratio, Debt Equity Ratio, Debt Asset Ratio, Dan Perputaran Modal Kerja Terhadap Return On Asset," Diponegoro J. Account., vol. 03, no. 2, 2014, pp. 1-13.

[24] N. E. Nainggolan and A. Rohman, "Pengaruh Struktur Corporate Governance Terhadap Pengungkapan Lingkungan," Diponegoro J. Account., vol. 4, no. 2, 2015, pp. 190-198.

[25] M. S. Pasaribu and M. Haryanto, "Pengaruh Financial Slack Terhadap Kinerja Keuangan Perusahaan Manufaktur Yang Terdaftar Di Bursa Efek Indonesia," Diponegoro J. Account., vol. 7, no. 4, 2018, pp. 1-9. 
[26] G. B. Voss, D. Sirdeshmukh, and Z. G. Voss, "The Effects Of Slack Resources And Environmental Threat On Product Exploration And Exploitation," Acad. Manag. J., vol. 51, no. 1, 2008, pp. 147-164, doi: 10.5465/AMJ.2008.30767373.

[27] Z. Zulkarnaen, "Pengaruh Debt To Assets Ratio Terhadap Return On Asset Pada Perusahaan Asuransi Yang Terdaftar Di BEI TAHUN $2010-$ 2015," J. War., vol. 2, no. 56, 2018, pp. 82-82, doi: 10.1007/0-387-26336-5_580. 